\title{
PENGARUH KUALITAS PRODUK, HARGA DAN PROMOSI TERHADAP KEPUTUSAN PEMBELIAN PRODUK HANDPHONE SAMSUNG PADA TOKO CENTRO PALOPO
}

\author{
Agunawan Andis ${ }^{1}$, M. Risal' ${ }^{2}$ Halim Usman ${ }^{3}$ \\ Email : Andis@gmail.com,mrisal@stiem.ac.id, halimusman@stiem.ac.id \\ ${ }^{1,2)}$ Prodi Manajemen Sekolah Tinggi Ilmu Ekonomi Muhammadiyah Palopo \\ ${ }^{3)}$ Prodi Akuntansi Sekolah Tinggi Ilmu Ekonomi Muhammadiyah Palopo
}

\begin{abstract}
Abstrak
Penelitian ini bertujuan untuk mengetahui pengaruh kualitas produk, harga dan promosi terhadap keputusan pembelian Handphone Samsung pada Toko Centro Palopo. Metode penelitian ini menggunakan metode kuantitatif dengan teknik pengambilan sampel non probability sampling atau pengambilan sampel secara tidak acak dengan teknik purposive sampling terhadap 100 orang yang membeli produk Handphone Samsung. Uji instrument dilakukan dengan uji validitas dan uji reabilitas. Metode analisis data dilakukan menggunakan uji statistik deskriptif dan uji hipotesis (analisis regresi linear berganda). Hasil penelitian menunjukkan bahwa kualitas produk mempunyai pengaruh yang signifikan terhadap keputusan pembelian Handphone Samsung, harga mempunyai pengaruh yang signifikan terhadap keputusan pembelian Handphone Samsung dan promosi mempunyai pengaruh yang signifikan terhadap keputusan pembelian Handphone Samsung. Simpulan dari penelitian ini adalah baik kualitas produk harga maupun promosi yaitu sama-sama memiliki hasil signifikan terhadap keputusan pembelian.

Kata Kunci : Kualitas Produk, Harga, Promosi, Keputusan Pembelian.
\end{abstract}

\section{PENDAHULUAN}

Perkembangan teknologi informasi dan komunikasi sangatlah cepat, sebagai akibat dari arus globalisasi. Salah satu perangkat teknologi informasi dan komunikasi yang mengalami perkembangan yang cepat adalah telepon seluler /handphone. Menurut (Jugiyanto, 2010) teknologi merupakan suatu kumpulan alat, aturan dan juga prosedur yang merupakan sebuah penerapan ilmiah dari sebuah pekerjaan tertentu. Teknologi bukan lagi menjadi halangan bagi kita dalam melakukan hubungan dengan orang lain, karena hubungan komunikasi dapat dilakukan kapanpun dan dimanapun. Untuk berbicara dengan orang lain diperlukan suatu komunikasi. Komunikasi merupakan suatu proses pertukaran informasi diantara individu melalui sistem lambanglambang, tanda-tanda, atau tingkah laku (Rochajat, 2011:20). Semua ini berkat semakin pesatnya perkembangan teknologi telekomunikasi yaitu sarana komunikasi berupa telepon. Pada awal perkembangan teknologi komunikasi masyarakat menganggap bahwa telepon kabel merupakan salah satu media komunikasi yang efektif dalam hubungan jarak jauh. Namun sejalan dengan perkembangan teknologi informasi yang sangat pesat sarana telekomunikasi telepon kabel saat ini menjadi kurang efektif karena masih memiliki keterbatasan. Menurut Williams \& Sawyer (2011), smartphone adalah telepon selular dengan mikroprosesor, memori, layar dan modem bawaan. Smartphone merupakan ponsel multimedia yang menggabungkan fungsionalitas $\mathrm{PC}$ dan handset sehingga menghasilkan gadget yang mewah, di mana terdapat pesan teks, kamera, pemutar musik, video, game, akses email, tv digital, search engine, pengelola informasi pribadi, fitur GPS, jasa telepon internet dan bahkan terdapat telepon yang juga berfungsi sebagai kartu kredit.

Dengan perkembangan teknologi yang semakin canggih, masyarakat membutuhkan suatu media komunikasi yang mampu menyerap arus komunikasi secara cepat dan tepat. Alat komunikasi telepon adalah alat komunikasi yang digunakan untuk menyampaikan pesan suara (terutama pesan yang berbentuk percakapan). Kebanyakan 


\section{ISSN : 2339-1510}

telepon beroperasi dengan menggunakan transmisi sinyal elektrik dalam jaringan telepon sehingga memungkinkan pengguna telepon untuk berkomunikasi dengan pengguna lainya. Smartphone yang dapat diartikan sebagai "telepon genggam /tangan yang pintar", merupakan sebuah alat komunikasi elektronik yang mempunyai kemampuan dasar yang sama dengan telepon konvensional saluran tetap (telepon kabel), namun dapat dibawa ke manamana (portabel, mobile) dan tidak perlu disambungkan dengan jaringan telepon menggunakan kabel (nirkabel; wireless). Sehingga kita dapat berkomunikasi dari sembarang tempat, selama masih ada jaringan sinyal untuk HP yang kita gunakan.

Berkembangnya sarana telekomunikasi yang semakin pesat, sejalan dengan kebutuhan dari masyarakat membuka peluang bagi perusahaan untuk memproduksi handphone yang sesuai dengan kebutuhan masyarakat. Peluang yang besar membuat perusahaan bersaing lebih kompetitif untuk memenangkan persaingan dengan cara mengenal, mencermati, dan mampu mengetahui apa yang dibutuhkan dan diinginkan oleh konsumen. Saat ini, peranan ponsel smartphone sudah menjadi sebuah kebutuhan primer sehari-hari. Orangorang sudah bisa dibilang tidak dapat lepas dari ponsel, dikarenakan hampir semua orang telah memiliki ponsel, dari yang kaya hingga yang miskin, dari anak-anak hingga orang dewasa. Lembaga riset Indonesia Data Center mengungkap data penjualan smartphone di Indonesia. Mereka membeberkan, ada 9.342.961 unit smartphone yang telah terjual sepanjang 2017. Lembaga riset ini memaparkan ada 5 merek smartphone yang merajai pasar smartphone di Indonesia. Berikut ini daftar lengkapnya:

Indonesia Top 5 Smartphone Companies, 201703 Unit Market Share

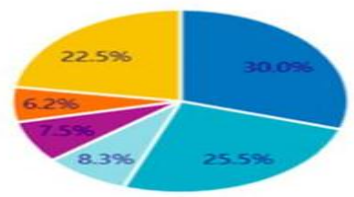

- Samsung =OPPo = Advan = vivo m =xiaomi =0thers

Gambar 1. Grafik Penjualan

Sumber: Indonesia Data Center Tahun 2017
Dari grafik penjualan handphone diatas Samsung memuncaki penjualan handphone terbanyak pada tahun 2017 sebanyak 30\%. Sebagai pemain utama dalam pasar handphone Indonesia, Samsung tetap akan kuat dan mendominasi pasar. "Samsung tetap berada di posisi pertama amount value untuk market share Indonesia (IDC 2017). Dari keterangan grafik tersebut produk Samsung sangat mendominan terhadap pengguna telepon genggam di indonesia. Samsung adalah perusahaan pembuat perangkat elektronika terbesar di Dunia dan merupakan ikon dari Samsung Group yang merupakan konglomerasi terbesar di Korea Selatan dan berkantor pusat di Seocho Samsung Town di Seoul, Korea Selatan. Samsung memulai sejarahnya pada tahun 1938 awalnya sebagai perusahaan trading, mengirimkan ikan kering dan buahbuahan dan didirikan oleh Lee ByungChul. Pertama kali Samsung mengeluarkan handphone pada dekade 90'an. Samsung Group mengeluarkan Mobile Phone (handphone) berawal mengikuti perkembangan jaman yang ternyata lumayan menarik pasar dunia. Sekarang harga Samsung terjangkau sehingga minat pembeli pun semakin tinggi. Terlebih ditambah dengan tarif layanan Samsung di Indonesia semakin murah dan diperkirakan akan lebih terjangkau, serta harga telepon seluler (ponsel) Samsung keluaran baru pun kian murah sehingga penggunanya tak hanya konsumen kelas atas (Anwar, I. (2010)).

Suatu merek memberikan berbagai macam petunjuk bagi para pelanggan, termasuk di dalamnya bisnis, budaya, penampilan, proses pekerjaan, dan juga trademark. Sekali suatu merek diterima oleh konsumen, maka pemasaran produk jasa akan lebih mudah diterima. Ketika hampir semua perusahaan menawarkan produk yang hampir seragam, maka kualitas, identitas, dan merek perusahaan menjadi hal yang sangat penting untuk membedakannya dengan produk lainnya.

Handphone menjadi salah satu barang yang paling dicari di kota besar seperti kota Palopo khususnya di Toko Centro, Jl Andi Djemma No. 152 kota Palopo. Selain itu merek ternama juga masih menjadi primadona di salah satu toko elektronik terbesar di Kota Palopo ini.

Berdasarkan latar belakang masalah tersebut, maka rumusan masalah dari penelitian 


\section{ISSN : 2339-1510}

ini yaitu Apakah kualitas produk berpengaruh signifikan terhadap keputusan pembelian konsumen pada produk Handphone Samsung pada Toko Centro Palopo ? Apakah harga berpengaruh signifikan terhadap keputusan pembelian konsumen terhadap Handphone Samsung pada Toko Centro Palopo ? Apakah promosi berpengaruh signifikan terhadap keputusan pembelian pada produk Handphone Samsung pada Toko Centro Palopo ?.

Berdasarkan uraian latar belakang dan rumusan masalah yang ada tersebut maka tujuan dari penelitian ini adalah sebagai berikut: untuk mengetahui apakah kualitas produk berpengaruh signifikan terhadap keputusan pembelian konsumen produk Handphone Samsung pada Toko Centro Palopo. untuk mengetahui apakah harga berpengaruh signifikan terhadap keputusan pembelian konsumen produk Handphone Samsung pada Toko Centro Palopo, untuk mengetahui apakah promosi berpengaruh signifikan terhadap keputusan pembelian konsumen produk Handphone Samsung pada Toko Centro Palopo.

\section{METODE PENELITIAN}

Jenis data yang digunakan yaitu data primer. Dimana peneliti menggunakan angket atau kuesioner untuk mengumpulkan informasi. Populasi dalam penelitian ini adalah masyarakat Kota Palopo yang memiliki minat membeli produk handphone Samsung Pada Toko Sentro sebanyak 100 orang konsumen. Sampel adalah bagian dari populasi yang diharapkan mampu mewakili populasi dalam penelitian ini jadi jumlah sampel yang digunakan untuk menentukan jumlah sampel adalah 100 orang dan semua popoulasi dijadikan sampel. Metode analisis data yang digunakan yaitu analisis regresi linier berganda. Dimana persamaan regresinya yaitu:

$\mathrm{Y}=\mathrm{a}+\mathrm{b}_{1} \mathrm{X}_{1}+\mathrm{b}_{2} \mathrm{X}_{2}+\mathrm{b}_{3} \mathrm{X}_{3}+\mathrm{e}$

Dimana:

$\begin{array}{ll}\mathrm{a} & : \text { Konstanta } \\ \mathrm{b}_{1}-\mathrm{b}_{3} & : \text { Koefisien regresi } \\ \mathrm{Y} & : \text { Keputusan Pembellian } \\ \mathrm{X}_{1} & : \text { Kualitas Produk } \\ \mathrm{X}_{2} & : \text { Harga } \\ \mathrm{X}_{3} & : \text { Promosi } \\ \mathrm{e} & : \text { error }\end{array}$

\section{PEMBAHASAN}

\section{Hasil Uji Validitas dan Reliabilitas \\ Hasil Uji Validitas}

Berikut hasil uji validitas instrument kuesioner penelitian:

Tabel 1. Hasil Uji Validitas

\begin{tabular}{|c|c|c|c|}
\hline Variabel & Item & $\begin{array}{l}\text { Sig. (2- } \\
\text { tailed) }\end{array}$ & keterangan \\
\hline \multirow{4}{*}{$\begin{array}{l}\text { Kualitas } \\
\text { produk }\end{array}$} & $\mathrm{P} 1$ & 0,824 & Valid \\
\hline & $\mathrm{P} 2$ & 0,786 & Valid \\
\hline & $\mathrm{P} 3$ & 0,807 & Valid \\
\hline & $\mathrm{P} 4$ & 0,801 & Valid \\
\hline \multirow{3}{*}{ Harga } & $\mathrm{P} 1$ & 0,846 & Valid \\
\hline & $\mathrm{P} 2$ & 0,685 & Valid \\
\hline & $\mathrm{P} 3$ & 0,796 & Valid \\
\hline \multirow{3}{*}{ Promosi } & $\mathrm{P} 1$ & 0,566 & Valid \\
\hline & $\mathrm{P} 2$ & 0,902 & Valid \\
\hline & $\mathrm{P} 3$ & 0,841 & Valid \\
\hline \multirow{4}{*}{$\begin{array}{l}\text { Keputusan } \\
\text { pembelian }\end{array}$} & $\mathrm{P} 1$ & 0,735 & Valid \\
\hline & $\mathrm{P} 2$ & 0,588 & Valid \\
\hline & $\mathrm{P} 3$ & 0,745 & Valid \\
\hline & $\mathrm{P} 4$ & 0,760 & Valid \\
\hline
\end{tabular}

Berdasarkan pada tabel diatas keempat indikator variabel yang digunakan didalam penelitian ini terkategori valid.

\section{Hasil Uji Validitas}

Berikut hasil uji validitas instrument kuesioner penelitian:

Tabel 2. Hasil Uji Reliabilitas

\begin{tabular}{|c|c|c|}
\hline $\begin{array}{c}\text { Variabel } \\
\text { Penelitian }\end{array}$ & $\begin{array}{c}\text { Cronbach's } \\
\text { Alpha }\end{array}$ & Keterangan \\
\hline $\begin{array}{c}\text { Kualitas } \\
\text { Produk }\end{array}$ & 0,816 & Reliabel \\
\hline Harga & 0,816 & Reliabel \\
\hline Promosi & 0,817 & Realibel \\
\hline $\begin{array}{c}\text { Keputusan } \\
\text { Pembelian }\end{array}$ & 0,781 & Realibel \\
\hline
\end{tabular}

Berdasarkan pada tabel diatas keempat indikator variabel yang digunakan didalam penelitian ini terkategori reliabel karena memiliki nilai Cronbach's Alpha $>0,60$. 


\section{Analisis Regresi Linear Berganda}

Berikut hasil pengujian hipotesis dengan menggunakan analisis regresi linier berganda:

Tabel 3. Hasil Analisis Regresi Linier Berganda

\begin{tabular}{|c|c|c|c|c|c|c|}
\hline \multicolumn{7}{|c|}{ Coefficients $^{\mathrm{a}}$} \\
\hline & \multirow{2}{*}{ Model } & \multicolumn{2}{|c|}{$\begin{array}{l}\text { Unstandardized } \\
\text { Coefficients }\end{array}$} & \multirow{2}{*}{$\begin{array}{c}\text { Standardized } \\
\text { Coefficients }\end{array}$} & \multirow{2}{*}{$\mathrm{t}$} & \multirow{2}{*}{ Sig. } \\
\hline & & B & $\begin{array}{l}\text { Std. } \\
\text { Error }\end{array}$ & & & \\
\hline \multirow{4}{*}{1} & (Constant) & 6.701 & 1.547 & & 4.333 & 0.000 \\
\hline & $\begin{array}{l}\text { Kualitas } \\
\text { Produk }\end{array}$ & 0.321 & 0.087 & 0.354 & 3.706 & 0.000 \\
\hline & Harga & 0.051 & 0.114 & 0.045 & 0.451 & 0.653 \\
\hline & Promosi & 0.277 & 0.103 & 0.258 & 2.694 & 0.008 \\
\hline
\end{tabular}

Sumber : Data primer

Berdasarkan hasil regresi linier berganda pada penelitian ini yang dilakukan maka variabel Kualitas Produk (X1), Harga (X2), dan Promosi (X3) Terhadap Kepuasan Pembeli (Y). Model persamaan regresi dihasilkan dalam bentuk persamaan regresi bentuk standar adalah sebagai berikut :

$\mathrm{Y}=6.701+0,321 \mathrm{X} 1+0,051 \mathrm{X} 2+0,277 \mathrm{X} 3+\mathrm{e}$

a) nilai konstanta sebesar 6.701 menunjukkan bahwa apabila nilai Kualitas Produk (X1), Harga (X2) dan Promosi (X3) konstan maka nilai Kinerja Karyawan (Y) sebesar 6.701

b) Nilai koefisien regresi variabel Kualitas Produk sebesar $\beta_{1}=0,321$ nilai positif tersebut menunjukkan jika kualitas produk sesuai dengan harapan konsumen maka akan meningkatkan keputusan pembelian terhadap Produk Handphone Samsung Pada Toko Centro Palopo.

c) Nilai koefisien regresi variabel Harga sebesar $\beta_{2}=0,051$ nilai positif tersebut menunjukan apabila ada peningkatan pada harga maka akan meningkatkan keputusan pembelian Produk Handphone Samsung Pada Toko Centro Palopo.

d) Nilai koefisien regresi variabel Promosi sebesar $\beta_{3}=0,277$ nilai positif tersebut menunjukan apabila ada peningkatan pada promosi maka akan meningkatkan kepuasan pembelian terhadap Produk Handphone Pada Toko Centro Palopo.

\section{Analisis Koefesien Determinasi $\left(\mathbf{R}^{2}\right)$}

Analisis koefisien determinasi digunakan untuk mengetahui seberapa besar persentase pengaruh variabel motivasi, kompensasi, dan pengalaman kerja secara bersama sama terhadap kinerja karyawan. Adapun hasil analisis koefisien determinasi dapat kita lihat pada tabel berikut ini:

Tabel 4. Hasil Analisis Regresi Linier Berganda

Model Summary

\begin{tabular}{|l|c|r|r|r|}
\hline Model & $\mathrm{R}$ & $\mathrm{R}$ Square & $\begin{array}{c}\text { Adjusted R } \\
\text { Square }\end{array}$ & $\begin{array}{c}\text { Std. Error of the } \\
\text { Estimate }\end{array}$ \\
\hline 1 & $.517^{\mathrm{a}}$ & .267 & .244 & 1.905 \\
\hline
\end{tabular}

Sumber : Data primer

Hasil perhitungan regresi dapat diketahui bahwa koefisien determinasi ( $R$ square) yang diperoleh sebesar 0,267. Hal ini berarti bahwa kualitas produk, harga dan promosi mampu menjelaskan keputusan pembelian sebesar $34,40 \%$, sedangkan 64,0 \% lainnya keputusan pembelian dijelaskan oleh variabel lain yang tidak diangkat pada penelitian ini.

\section{Uji t}

Berdasarkan hasil uji t pada tabel 3 maka dapat dilakukan pembuktian sebagai berikut :

1. Kualitas Produk (X1) menhasilkan koefisien nilai $\mathrm{t}$ sebesar 4.333, sedangkan nilai signifikannya sebesar 0,001 yang berati $0,001<0,05$, sedangkan nilai t hitung lebih besar dari t tabel yaitu $4.333>1,660$. Dari hasil tersebut dapat disimpulkan bahwa terdapat pengaruh yang signifikan atau adanya pengaruh Kualitas Produk terhadapKeputusan Pembelian. Hal ini berarti hipotesis pertama (H1) diterima

2. Harga (X2) menghasilkan koefisien nilai t sebesar 2.451, sedangkan nilai signifikannya sebesar 0.653 yang berarti $0.653<0,05$, sedangkan nilai $\mathrm{t}$ hitung lebih besar dari $\mathrm{t}$ tabel yaitu $2.451>1.660$. Dari hasil tersebut dapat disimpulkan bahwa terdapat pengaruh yang signifikan atau adanya pengaruh Harga terhadap Kualitas Produk. Hal ini berarti hipotesis kedua $(\mathrm{H} 2)$ diterima.

3. Promosi (X3) menghasilkan koefisien nilai $t$ sebesar 2.694, sedangkan nilai signifikannya sebesar 0,008 yang berati $0,008<0,05$, sedangkan nilai $\mathrm{t}$ hitung lebih besar dari $\mathrm{t}$ 
tabel yaitu $2.694>1,660$. Dari hasil tersebut dapat disimpulkan bahwa terdapat pengaruh yang signifikan atau adanya pengaruh Promosi terhadap nilaiKeputusan Pembelian. Hal ini berarti hipotesis ketiga diterima.

\section{Uji F}

Untuk menguji pengaruh variabel bebas (kualitas produk, harga dan promosi) secara bersama-sama diuji dengan menggunakan uji $\mathrm{F}$. Berpengaruh secara signifikan terhadap variabel terikat (keputusan pembelian) secara bersama-sama dengan $\alpha=0,05$ dan juga penerimaan atau penolakan hipotesis. Hasil perhitungan regresi secara simultan diperoleh sebagai berikut:

Tabel 5. Hasil Uji Simultan

ANOVA $^{\mathrm{a}}$

\begin{tabular}{|c|c|c|c|c|c|}
\hline Model & $\begin{array}{l}\text { Sum of } \\
\text { Squares }\end{array}$ & $\overline{\text { Df }}$ & $\begin{array}{l}\text { Mean } \\
\text { Square }\end{array}$ & $\bar{F}$ & Sig. \\
\hline $\begin{array}{c}\text { Regression } \\
\text { Residual } \\
\text { Total }\end{array}$ & $\begin{array}{c}126.772 \\
348.228 \\
475\end{array}$ & $\begin{array}{c}3 \\
96 \\
99\end{array}$ & $\begin{array}{l}42.257 \\
3.627\end{array}$ & 11.65 & $.000^{\mathrm{b}}$ \\
\hline
\end{tabular}

\section{Pembahasan Hasil Penelitian}

Pembahasan

1. Pengaruh Kualitas Produk terhadap Keputusan Pembelian Produk Handphone Samsung Pada Toko Centro Palopo

Berdasarkan hasil penelitian menunujukkan bahwa kualitas produk mempunyai pengaruh yang positif dan signifikan terhadap keputusan pembelian, dapat dilihat dari nilai $\mathrm{t}$ hitung adalah sebesar 3.706 dengan signifikansi sebesar 0,001 lebih kecil dari 0,05 Nilai koefisien regresi pada variabel kualitas produk bertanda positif, artinya terjadi pengaruh positif/searah antara kualitas produk dengan keputusan pembelian. Hasil penelitian ini sejalan dengam Fitria Isnaini (2015) menunjukkan bahwa kualitas produk berpengaruh signifikan secara positif terhadap keputusan pembelian karena suatu perusahaan dikatakan memiliki kualitas yang baik apabila mempunyai dampak positif terhadap perusahaan, meliputi peningkatan penjualan dan peningkatan citra perusahaan di mata masyarakat atas penggunaan produk perusahaan. Hal ini diperjelas melalui teori Kotler (2012) yang mengatakan bahwa konsumen mempunyai anggapan adanya hubungan positif antara harga dan kualitas produk, maka mereka akan membandingkan produk satu dengan yang lainnya dan barulah konsumen mengambil keputusan untuk membeli suatu produk.

2. Pengaruh Harga terhadap Keputusan Pembelian Produk Handphone Samsung Pada Toko Centro Palopo

Berdasarkan hasil penelitian menunujukkan bahwa harga mempunyai pengaruh yang positif dan signifikan terhadap keputusan pembelian, dapat dilihat dari nilai $\mathrm{t}$ hitung adalah sebesar 2.451 dengan signifikansi sebesar 0,653 lebih kecil dari 0,05 Nilai koefisien regresi pada variabel kualitas produk bertanda positif sebesar 0,653, artinya terjadi pengaruh positif/searah antara harga dengan keputusan pembelian. Hasil penelitian ini sejalan dengan Fitria Isnaini (2015) menunjukkan harga berpengaruh signifikan secara positif terhadap keputusan pembelian karena harga dapat menunjukkan kualitas merek dari suatu kualitas produk. Sehingga dengan penetapan harga yang tepat, mampu mempengaruhi konsumen untuk melakukan pembelian.

3. Pengaruh Promosi terhadap Keputusan Pembelian Produk Handphone Samsung Pada Toko Centro Palopo

Berdasarkan hasil penelitian menunujukkan bahwa promosi mempunyai pengaruh yang positif dan signifikan terhadap keputusan pembelian, dapat dilihat dari nilai $\mathrm{t}$ hitung adalah sebesar 2,694 dengan signifikansi sebesar 0,008 lebih kecil dari 0,05 Nilai koefisien regresi pada variabel promosi bertanda positif sebesar 2,694 , artinya terjadi pengaruh positif/searah antara harga dengan keputusan pembelian. Hasil penelitian ini sejalan dengan F.I Januarum Sari (2016) menunjukkan promsi berpengaruh signifikan terhadap keputusan pembelian Promosi mencerminkan kegiatakegiatan yang mengkomunikasikan keunggulan produk dan membujuk konsumen untuk membelinya. Jadi, promosi ini merupakan komponen yang dipakai untuk memberikan dan 
mempengaruhi pasar bagi produk perusahaan.

\section{SIMPULAN DAN SARAN Simpulan}

Berdasarkan analisis yang telah dilakukan dapat ditarik beberapa kesimpulan dari berbagai Bab antara lain sebagai berikut:

1. Hasil penelitian menunjukkan kualitas produk berpengaruh signifikan secara positif terhadap keputusan pembelian karena suatu perusahaan dikatakan memiliki kualitas yang baik apabila mempunyai dampak positif terhadap perusahaan, meliputi peningkatan penjualan dan peningkatan citra perusahaan di mata masyarakat atas penggunaan produk perusahaan.

2. Hasil penelitian menunjukkan harga berpengaruh signifikan secara positif terhadap keputusan pembelian karena harga dapat menunjukkan kualitas merek dari suatu kualitas produk. Sehingga dengan penetapan harga yang tepat, mampu mempengaruhi konsumen untuk melakukan pembelian.

3. Hasil penelitian menunjukkan promsi berpengaruh signifikan terhadap keputusan pembelian Promosi mencerminkan kegiatakegiatan yang mengkomunikasikan keunggulan produk dan membujuk konsumen untuk membelinya. Jadi, promosi ini merupakan komponen yang dipakai untuk memberikan dan mempengaruhi pasar bagi produk perusahaan.

4. Hasil penelitian perhitungan uji $\mathrm{F}$ diatas dapat disimpulkan bahwa kualitas produk, harga dan promosi secara bersama-sama berpengaruh secara simultan terhadap keputusan pembelian.

\section{Saran}

Melihat semakin tinggi persaingan antar produsen handphone diharapkan selalu meningkatkan kualitas produk, mempertahankan citra yang baik di mata masyarakat, dan penetapan harga yang sesuai dengan manfaat produk dan daya beli masyarakat. Mengingat perkembangan teknologi yang semakin canggih dapat mempengaruhi keputusan pembelian seseorang.

\section{DAFTAR PUSTAKA}

Anwar, I . 2010. Sejarah telepon seluler. http:// teknologi.kompasiana.com/

gadged/2010/02/17/ sejarah-teleponseluler/

Basu Swasta dan Irawan. 2010. Manajemen Pemasaran Modern. Yogyakarta: Liberty.

Bayu Prawira dan Ni Nyoman Kerti Yasa. 2014. Pengaruh Kualitas Produk, Citra Merek dan Persepsi Harga terhadap Minat Beli Produk Smartphone Samsung di Kota Denpasar.

Fandy Tjiptono. 2013. Prinsip-prinsip Total Quality Service. Yogyakarta: Andi Offset.

Hidayat, Rachmat. 2013. Pengaruh Kualitas Layanan, Kualitas Produk dan Nilai Nasabah Terhadap Kepusan dan Loyalitas Nasabah Bank Mandiri. Jurnal Manajemen dan Kewirausahaan.

Jogiyanto, H. M 2010. Analisis Rancangan Sistem Informasi: pendekatan terstruktur dan praktek aplikasi bisnis. Yogyakarta: Andi Offset.

Kinnear, Thomas C. dan James R. Taylor. 1995. Marketing Research. New York: McGraw Hill Text.

Kotler, Philip. 2010. Manajemen Pemasaran. Jakarta : Erlangga

Kotler, P. dan Amstrong, G. 2011. Dasardasar Pemasaran, Edisi Kesembilan Jilid 1. Jakarta: Indeks.

Kotler, Philip dan Amstrong, Gray. 2011. 10 ${ }^{\text {th }}$ edition. Marketing an introduction. Indonesia. Pearson.

Kotler, Philip \& Garry Armstrong, 2010, Principles of Marketing, Twelfth Edition, (Terjemahan Bob Sabran), Erlangga. Jakarta.

Kotler, P. 2011. Manajemen Pemasaran. Jilid 2. Edisi kesebelas. Alih Bahasa Benyamin Molan. Jakarta: Prenhallindo.

Kotler, P. 2012. Manajemen Pemasaran, Analisis Perencanaan, Implementasi Dan Kontrol. Terjemahan Hendra 
Teguh dan Ronny Antonius Rusly. Jakarta: PT. Prehallindo.

Kotler, P. dan Amstrong, G. 2012. Prinsip-prinsip Pemasaran, Edisi Keduabelas Jilid 1.Jakarta: Erlangga.

Kotler, P. dan Amstrong, G. 2012. Prinsip-prinsip Pemasaran, Edisi Ketigabelas Jilid 1.Jakarta: Erlangga.

Kotler, P. dan Keller, Kevin L. 2012. Manajemen Pemasaran, Edisi Ketigabelas Jilid 2. Terjemahan Bob Sabran, MM. Jakarta: Erlangga.

Kumala. 2012. Pengaruh Word of Mouth Terhadap Minat Beli Konsumen Pada Tune Hotels Kuta Bali. Skripsi. Universitas Indonesia, Jakarta.

Mullin, John W, dan Orville C Walker. 2014. Marketing Management A Strategic Decision. fifth edition. New York: McGraw Hill.

Sukrino, Sadono. 2012. Mikroekonomi Teori Pengantar. Catatan ke-19 dan ke27. PT. Raja Grafindo Persada, Jakarta.

Shandy Widjoyo dan Prof. Dr. Hartono Samuel. 2014. Pengaruh Kualitas Layanan Dan Kualitas Produk Terhadap Kepuasan Pelanggan Dan Loyalitas Konsumen Restoran Happy Garden Surabaya. Jurnal Manajemen Pemasaran, Vol. 2. No. 1 